\title{
Geophysical investigation of banded iron ore mineralization at Ero, North - Central Nigeria
}

\section{Geofizilkalna prospekcija pasovite železove rude pri Eru v severni osrednji Nigeriji}

\author{
Kayode Oyedele, Sunday Oladele*, Anthony Salami \\ Department of Geosciences, University of Lagos \\ *Corresponding author: soladele@unilag.edu.ng
}

\begin{abstract}
The banded iron ore mineralization at Ero was investigated using aeromagnetic, resistivity and induced polarization (IP) methods with the aim of characterizing the deposit. Analysis of the aeromagnetic data involved the application of reduced-to-equator transformation, derivative filters, analytic signal and source parameter imaging techniques. Computer modelling of some of the identified anomalies was undertaken. The electrical resistivity and IP methods helped in discriminating between the iron ore and the host rock. The results showed that the banded iron formations (BIFs) were characterized by spherical analytic signal anomalies ranging from $0.035 \mathrm{nT} / \mathrm{m}$ to $0.06 \mathrm{nT} / \mathrm{m}$ within the granite gneiss and magnetic susceptibility of 0.007-0.014 SI. The iron ore had low chargeability (0.1-5.0 msec) and resistivity $\left(1.5 \times 10^{2}\right.$ to $\left.2.5 \times 10^{3} \Omega \mathrm{m}\right)$. Structural features trending in the NE-SW, E-W, and NW-SE were identified, suggesting that the area had undergone many episodes of tectonic events. Depth to the BIF varied from the surface up to about $200 \mathrm{~m}$. The chargeability response of the iron bodies suggested an average grade of $20 \%-40 \%$, making the prospect for economic exploitation attractive.
\end{abstract}

Key words: iron ore, chargeability, structure, analytic signal, magnetic models

\section{Izvleček}

Pasovito železovo orudenje pri Eru so preiskovali z aeromagnetno, upornostno in inducirano polarizacijsko (IP) metodo z namenom opredeliti nahajališče. Analiza aeromagnetnih podatkov je obsegala transformacijo po metodi redukcije na ekvator (RTE), derivativno filtriranje in vizualizacijo analiznega signala ter parametrov vira, Opravili so računarniško modeliranje nekaterih ugotovljenih anomalij. Za ločevanje železove rude od prikamnine so uporabili metode elektroodpornosti in inducirane polarizacije. Rezultati kažejo, da so za pasovite železove rude (BIF, banded iron formations) v granitnem gnajsu značilne anomalije sferičnega analiznega signala med $0,035 \mathrm{nT} / \mathrm{m}$ in $0,06 \mathrm{nT} / \mathrm{m}$ in magnetne susceptibilnosti med 0,007 SI in 0,014 SI. Za železovo rudo sta značilna nizek padec napetosti $(0,1-5 \mathrm{sek})$ in upornost $\left(1.5 \times 10^{2}-2.5 \times 10^{3} \Omega \mathrm{m}\right)$. Ugotovili so structure v smereh NE-SW, E-W in NW-SE, ki pričajo o tektonskih dogajanjih. Rude BIF se raztezajo od površja do približno 200 m globine. Podatki inducirane polarizacije kažejo na povprečne vsebnosti $20 \%$ do $40 \%$ železa $\mathrm{v}$ udnih telesih, kar je primerno za gospodarno izkoriščanje nahajališča.

Ključne besede: železova ruda, inducirana polarizacija, strukture, analizni signal, magnetometrični modeli 


\section{Introduction}

Iron is the sixth most abundant element in the universe and the most abundant metal in the earth's crust after aluminium [1]. Iron ores include hematite, magnetite, limonite and pyrite among others. The two broad types of iron ore deposits in Nigeria are the banded iron formation (BIF), which occurs in folded bands and lenses associated with the Precambrian meta-sedimentary schist belts, and the Cretaceous sedimentary (oolitic) deposits. BIFs are chemical sedimentary rocks characterized by alternating layers of iron -rich minerals and chert [2]. Many studies have been carried out on iron ore deposits in different parts of the country [3-5]. On the basis of the iron content, iron ore can be classified into low (less than $30 \%$ iron), medium (30 $-50 \%$ iron) and high grade (more than 50\%) [6]. This study was aimed at identifying anomalous zones for possible iron ore mineralization and at determining their physical properties using magnetic and electrical methods. Magnetic surveying has played a major role in the deli neation of iron ore deposits, and exploration for such deposits based on their magnetic effects represents the earliest use of geophysics in mineral exploration $[7,8]$. The electrical resistivity and induced polarization (IP) methods also have their application in mineral exploration $[9,10]$. The IP method plays a very useful role in mineral exploration, especially when there is little resistivity contrast between target and host [11].

\section{Site description}

The study area is located within longitudes $6^{\circ} 37^{\prime} 15^{\prime \prime} \mathrm{E}-6^{\circ} 41^{\prime} 56^{\prime \prime} \mathrm{E}$ and latitudes $7^{\circ} 32^{\prime} 25^{\prime \prime} \mathrm{N}-7^{\circ} 37^{\prime} \mathrm{N}$, near Ero Village, Kogi State, North -Central Nigeria (Figure 1). It covers an area of approximately $21 \mathrm{~km}^{2}$ and is accessible through the Lokoja-Ajaokuta Road. The terrain is mainly undulating, with gentle hills separated by lowlands with flat soil cover, except for the north -eastern part, which has a very steep and massive outcrop. Elevation varies from $45 \mathrm{~m}$ to $550 \mathrm{~m}$ above mean sea level. The drainage pattern in the area is dendritic and the area is principally drained by the River Ero.

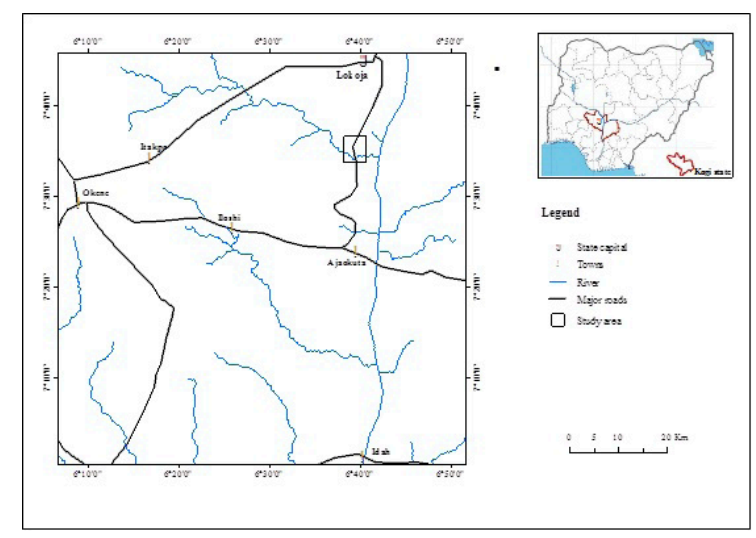

Figure 1: Location map of the study area (digitized and extracted from Sheet 62, Geological Survey of Nigeria).

\section{Geology of the study area}

The study area is situated within the south-western Nigeria basement complex and is made up of rocks, which include migmatite gneiss (granite gneiss and biotite gneiss), coarse-grained porphyritic granite and medium- to coarse-grained granite intruded by the NE -SW - and NW -SE - trending pegmatite, quartz veins and quartzo-feldspathic veins [12-14]. It lies within the meta-sedimentary iron formation belonging to the Lokoja-Okene -Kabba triangle (Figure 2), which hosts most of Nigeria's Pre-Cambrian low-grade iron ore deposits, consisting of the oxide and silicate facies [15]. The Itakpe Hill iron ore deposit, the largest of several similar deposits occurring in the district, has been described as a hematite -magnetite -quartz body and is termed as a ferruginous quartzite of the itabirite type [12]. Within the study area, outcrops of BIFs are observed, which are associated with $\mathrm{N}-\mathrm{S}$-trending structural features (Figure 3).

\section{Materials and methods}

The materials used for this work include the topographic map, as well as the aeromagnetic, resistivity and IP data. The topographic map was obtained during the Shuttle Radar Topography Mission (SRTM), which was a space shuttle mission carried out by the National Aeronautics and Space Administration (NASA) in February 2000, while the aeromagnetic data 

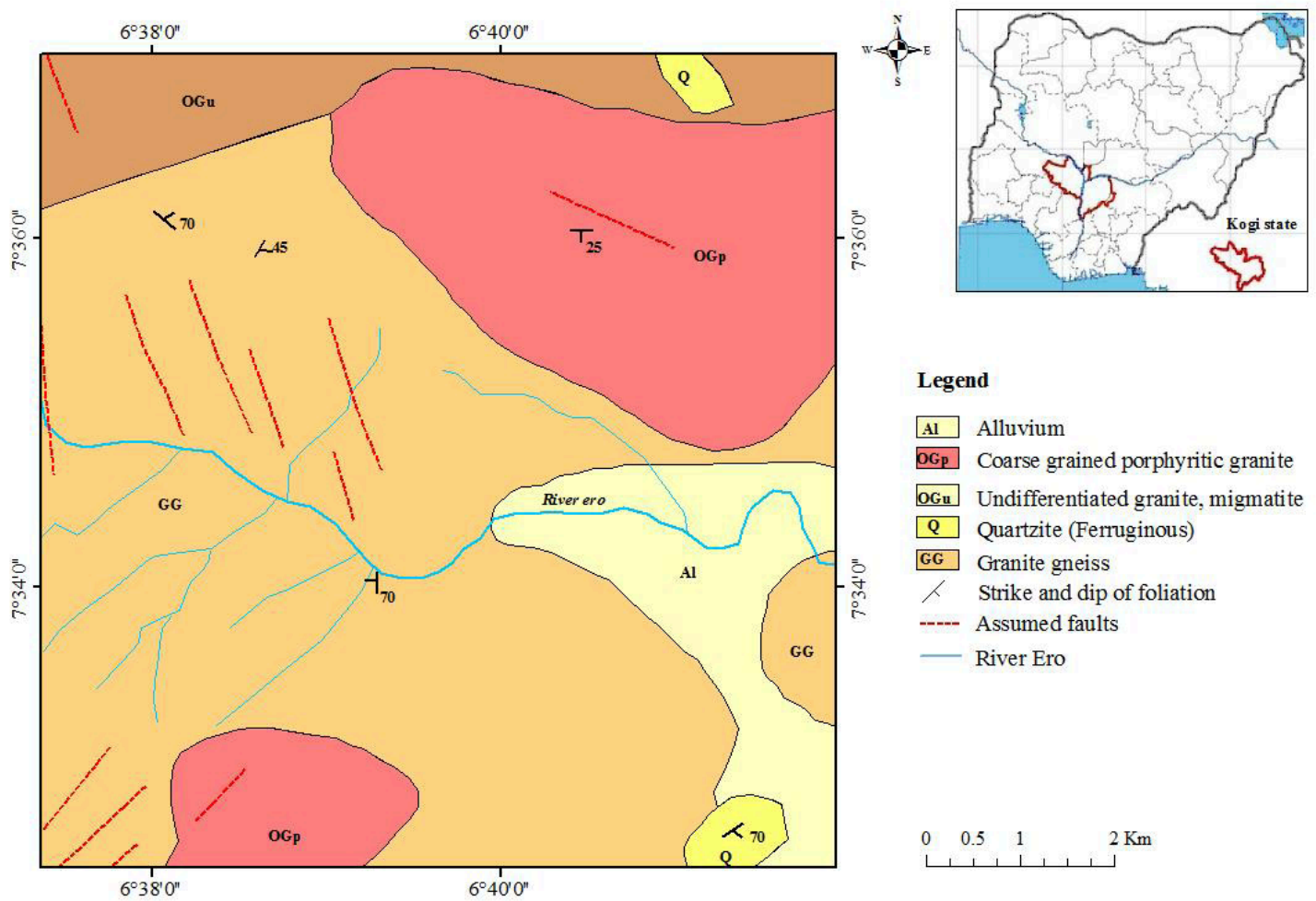

Legend

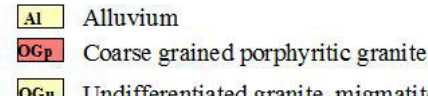

OGu Undifferentiated granite, migmatite

Q Quartzite (Ferruginous)

GG Granite gneiss

$<\quad$ Strike and dip of foliation

---- Assumed faults

— River Ero

Figure 2: Regional geological map of the study area (digitized and extracted from Sheet 62, Geological Survey of Nigeria).

were acquired by the Nigerian Geological Survey Agency. Aeromagnetic data covering the area (Sheet 247) was used for this study. The data were acquired at a terrain clearance of $80 \mathrm{~m}$, flight line spacing of $500 \mathrm{~m}$ and tie line spacing of $2 \mathrm{~km}$. The flight direction for the survey was the NW -SE direction, while the tie line direction was NE -SW. The geomagnetic gradient was removed from the acquired data using the 2005 International Geomagnetic Reference Field. Electrical resistivity and IP data were acquired by the authors during a 4 day geophysical survey.

\section{Aeromagnetic data analysis}

The reduced-to-equator (RTE) transformation [16] of the aeromagnetic data, which removed the asymmetry in the magnetic field due to declination, was performed using an average inclination and declination of $-9.3^{\circ}$ and $-2.5^{\circ}$, respectively, and an amplitude correction inclination of $20^{\circ}$. The RTE map was continued upwards to a height of $100 \mathrm{~m}$ and subtracted from the RTE total magnetic field intensity to obtain the residual magnetic field. The filter used for the upward continuation operation

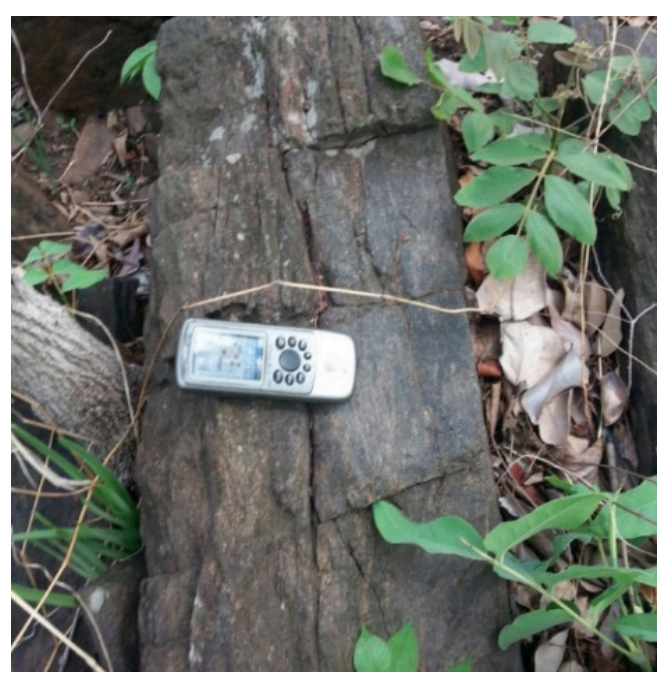

Figure 3: Outcrop of the banded iron formation.

allows the transformation of data measured on one surface to some higher surface [17] and tends to smooth the original data by attenuating the short-wavelength anomalies relative to their long-wavelength anomalies. Edge detection of the magnetic anomalies was carried out using the technique of analytic signal [18]. This technique is very useful particularly where remanence and/or low magnetic latitude compli- 
cates interpretation. Its major advantage is that its amplitude peaks over magnetic sources regardless of the direction of magnetization [19]. It uses the first-order horizontal and vertical derivatives of the given magnetic anomaly field and can be expressed as follows:

$\left|A_{(x, y)}\right|=\sqrt{\left(\frac{d}{d x} F_{(x, y)}\right)^{2}+\left(\frac{d}{d y} F_{(x, y)}\right)^{2}+\left(\frac{d}{d} F_{(x, y)}\right)^{2}}$

The depth estimate of the magnetic source was achieved using the source parameter imaging procedure[20]. It is based on the complex analytic signal technique, which computes source parameters from gridded magnetic data.

Depth $=\frac{1}{K_{\max }}$

where

$\mathrm{K}_{\max }=\left\{\left(\sqrt{\left(\frac{\mathrm{dTilt}}{\mathrm{dx}}\right)^{2}+\left(\frac{\mathrm{dTilt}}{\mathrm{dy}}\right)^{2}}\right)\right\} \max$

The second vertical derivative (SVD) and the total horizontal derivative (THDR) were used to accentuate near-surface features (Telford et $a l, 1990)$. The biggest advantage of the THDR is its low susceptibility to noise as it requires only the calculation of the two first-order horizontal derivatives of the field. The maximum amplitude of this function tends to overlie the edges of a causative source if the edges are vertical and well separated from each other [21].

$\operatorname{SVD}=\frac{\mathrm{d}^{2}}{\mathrm{dz}^{2}} \mathrm{~F}_{(\mathrm{x}, \mathrm{y})}$

THDR $=\sqrt{\left(\frac{d}{d x} F_{(x, y)}\right)^{2}+\left(\frac{d}{d y} F_{(x, y)}\right)^{2}}$

where $F$ is the total magnetic field.

Next, two-dimensional (2D) magnetic models were generated along two profiles (L1 and L2) across some of the BIF magnetic anomalies and structures. The created blocks representing the various rock units were colour-coded and labelled.

\section{D Resistivity and IP data analysis}

To ascertain the BIF anomalies identified on the aeromagnetic map, electrical resistivity and IP data sets were acquired simultaneously across three $120 \mathrm{~m}$-long profiles using the ABEM SAS 4000 Terrameter, using four stainless steel rods as the current and potential electrode pairs. Both the lateral and vertical variations in the subsurface electrical properties were investigated concurrently as it provides a more accurate image of the subsurface in two dimensions [22]. The Wenner array (geometric factor,) was chosen due to its good resolution of vertical changes, moderate depth of investigation and its strong signal-to-noise ratio, which is a very important factor in areas with high background noise [22]. The smallest inter-electrode separation used was $5 \mathrm{~m}$ and deeper investigative depth was achieved by increasing this separation by integer values $\mathrm{N}$ (where $\mathrm{N}=$ $1,2,4,6$ and 8). Inversion of the apparent resistivity and chargeability data sets was carried out using the RES2DINV software version 3.53. A forward-modelling subroutine was used to calculate the apparent resistivity values, and a on -linear least -squares optimization technique was used for the inversion routine [23].

\section{Results and discussion}

\section{Magnetic anomalies}

The topographic map (Figure 4) showed two granite hills that induced topography-related aeromagnetic anomalies. The residual aeromagnetic map (Figure 5) showed magnetic anomalies with amplitudes ranging between $-143 \mathrm{nT}$ and $117 \mathrm{nT}$. The north -western part is characterized mostly by positive anomalies in the range of $10-117 \mathrm{nT}$, bounded on the northern and southern parts by mostly negative-amplitude anomalies ranging between $-2 \mathrm{nT}$ and $-143 \mathrm{nT}$. This variation in magnetic field is indicative of the variation in the magnetic susceptibilities of the subsurface rocks. Some prominent linear and broad magnetic anomalies with high and low gradients and closures with $\mathrm{E}-\mathrm{W}$ and $\mathrm{NE}-\mathrm{SW}$ trends can also be observed. The closely spaced rugged contour pattern observed in the central portion with positive magnetic intensity response could be 


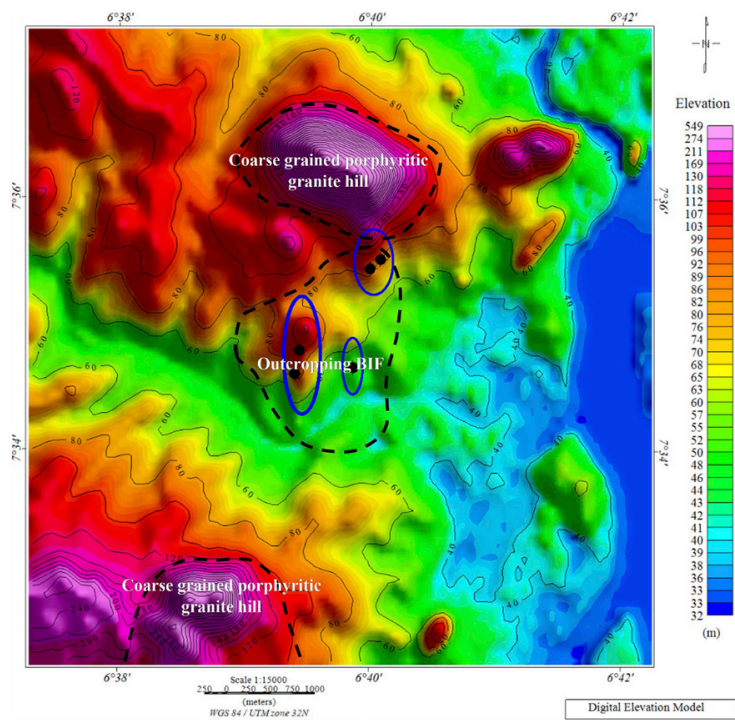

Figure 4: Shuttle Radar Topography Mission elevation map of the study area.

interpreted as being due to a low-susceptibility body occurring very close to the surface. This interpretation is consistent with the near-surface occurrence of the granite gneiss rock unit. The smaller-amplitude contour closures observed within this region could be due to the magnetic intrusive bodies associated with the rock unit.

\section{BIF identification/mapping}

The RTE residual map (Figure 6) shows various closures and highly negative magnetic intensity characteristic of magnetic sources. With the aid of the topographic map, some topographically induced magnetic anomalies were identified and isolated. The magnetic anomalies observed in the north -eastern and south -western parts of the map were attributed to the coarsegrained porphyritic granite hills present in the area (Figure 4). The analytic signal showed the distribution of isolated high-amplitude anomalies, with some of them coinciding with the areas of BIF outcroppings (Figure 7). The amplitude of these associated anomalies ranges between $0.035 \mathrm{nT} / \mathrm{m}$ and $0.06 \mathrm{nT} / \mathrm{m}$, with a characteristic spherical/oval shape. Eight target anomalies (A, B, C, D, E, F, G, H and I) were identified based on this pattern recognition. Iron ore within this area is hosted in the granite gneiss rock units [12]. On the basis of this observation, the anomalies were further discrim-

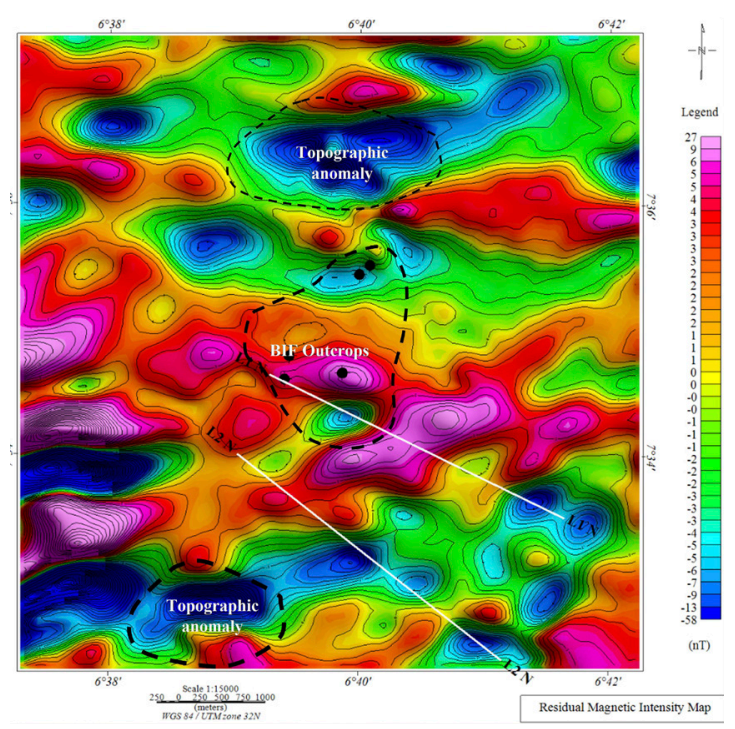

Figure 5: Reduced-to-equator residual magnetic intensity map of the study area.

inated and those occurring within the granite gneiss rock units were identified as possible BIF mineralizations. These included targets A, B, D, E and I. Targets F, G and H were easily identified and were associated with the granite gneiss rock due to the magnetic transparency of alluvium deposit over the area where they occur. However, target $\mathrm{F}$ falls within the area of ferruginous quartzite on the regional geology map (Figure 3) and trends in the NE -SW direction. This observation is indicative of the possibility of the mineralization being structurally controlled in agreement with Amigun et al [3]. Target $C$ could not be ascertained due to its very high amplitude $(>0.30 \mathrm{nT} / \mathrm{m})$, which exceeds the range of the BIF, although based on the regional geology map, it occurs within the granite gneiss and is not topographically influenced by the topographic map.

\section{Depth estimate}

Figure 8 shows the variation in depth of various magnetic sources within the study area. The displayed depths are estimated from the sensor height of $80 \mathrm{~m}$ above the ground level. Most of the target anomalies identified as being due to BIF mineralizations occur in regions having depths less than $200 \mathrm{~m}$ from the ground surface. This near-surface occurrence and thickness of the mineralization makes the area a viable prospect for iron ore exploitation. 


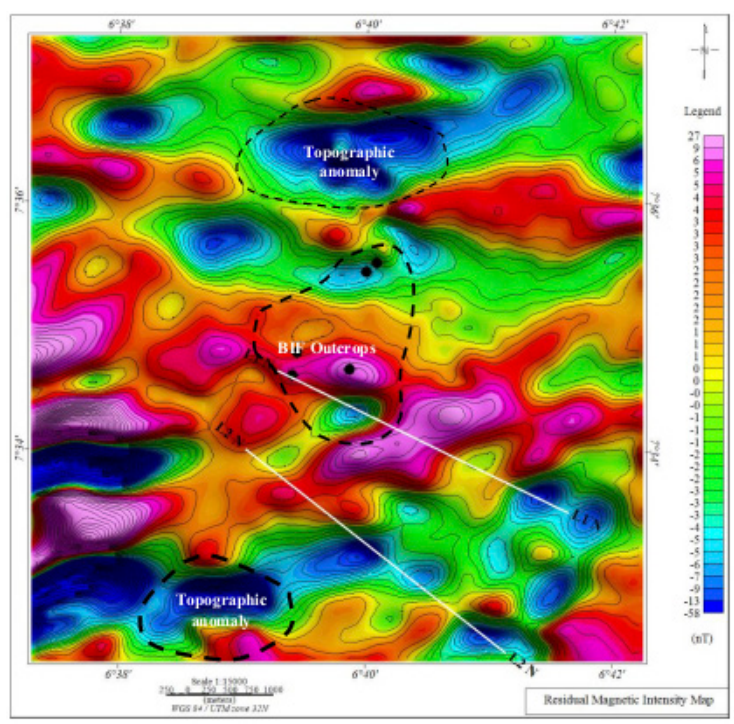

Figure 6: Reduced-to-equator residual magnetic intensity map of the study area showing the topographically induced anomalies, BIF outcrops and the modelled traverses.

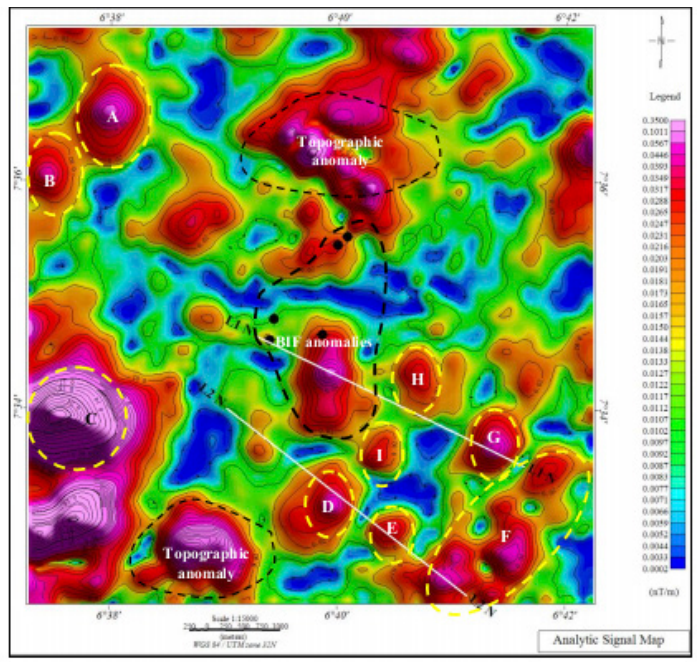

Figure 7: Analytic signal map of the study area showing the identified BIF and topographic anomalies.

\section{Structural mapping}

The lineaments mapped using SVD and THDR were combined to form the lineaments map (Figure 9). The lineaments were grouped into NE -SW, NW -SE and E -W based on their orientation, with the NE -SW direction having the dominant trend. NW -SE trends are prevalent in the northern part, while the NE -SW trend prevails in the southern part. The NE -SW structural trends, consistent with some of the intrusions and foliations within the study area, may probably have been Pan-African, while

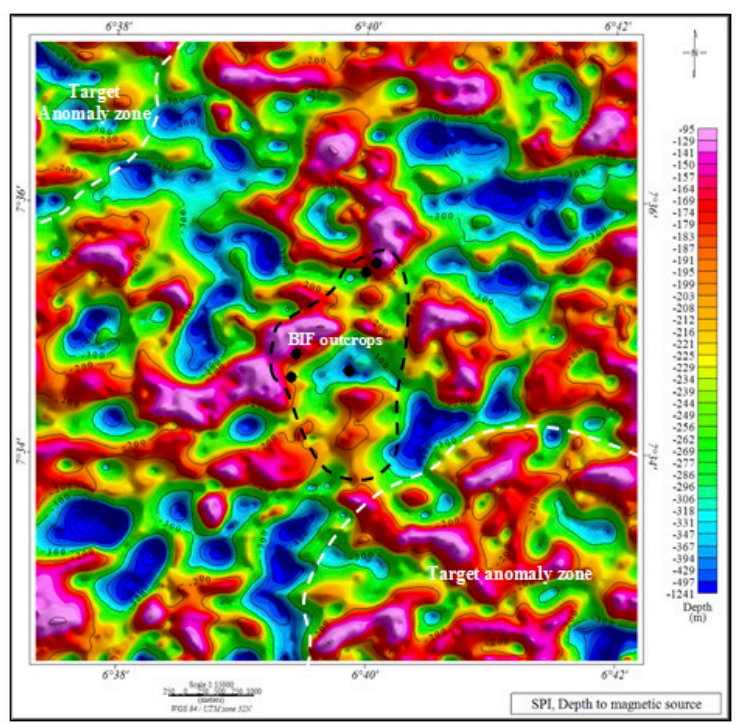

Figure 8: Source parameter imaging-derived map of depth to magnetic source in the study area.

the NW -SE and E -W trends may have been pre-Pan-African [24]. The delineated structural trends are in agreement with conclusions drawn from previous studies carried out on parts of the Nigerian basement complex using aeromagnetic data analysis $[25,26]$.

\section{D Magnetic Models}

Two magnetic models (Figures 10a and 10b) were created using a susceptibility range of $0.007-0.014$ SI for the BIF, $0.0000125-0004$ SI for the host rock (granite gneiss) and $0.019 \mathrm{SI}$ for the ferruginous quartzite. Profile L1 cut across targets F, G, H and the BIF outcrop zone. Profile L2 cut through targets D, E and F. The models were produced to a depth of about $200 \mathrm{~m}$ and show the iron mineralization occurring within the host rock, from the surface to a depth of about $150 \mathrm{~m}$. The root-meansquare errors between the simulated profile and the observed profile data range from 0.438 to 0.577 . This low error value implies a high degree of reliability of the simulated profiles. Comparison of the predicted models with the in situ geology reveals high degree of similarity. This demonstrates that the models are true representations of reality. 


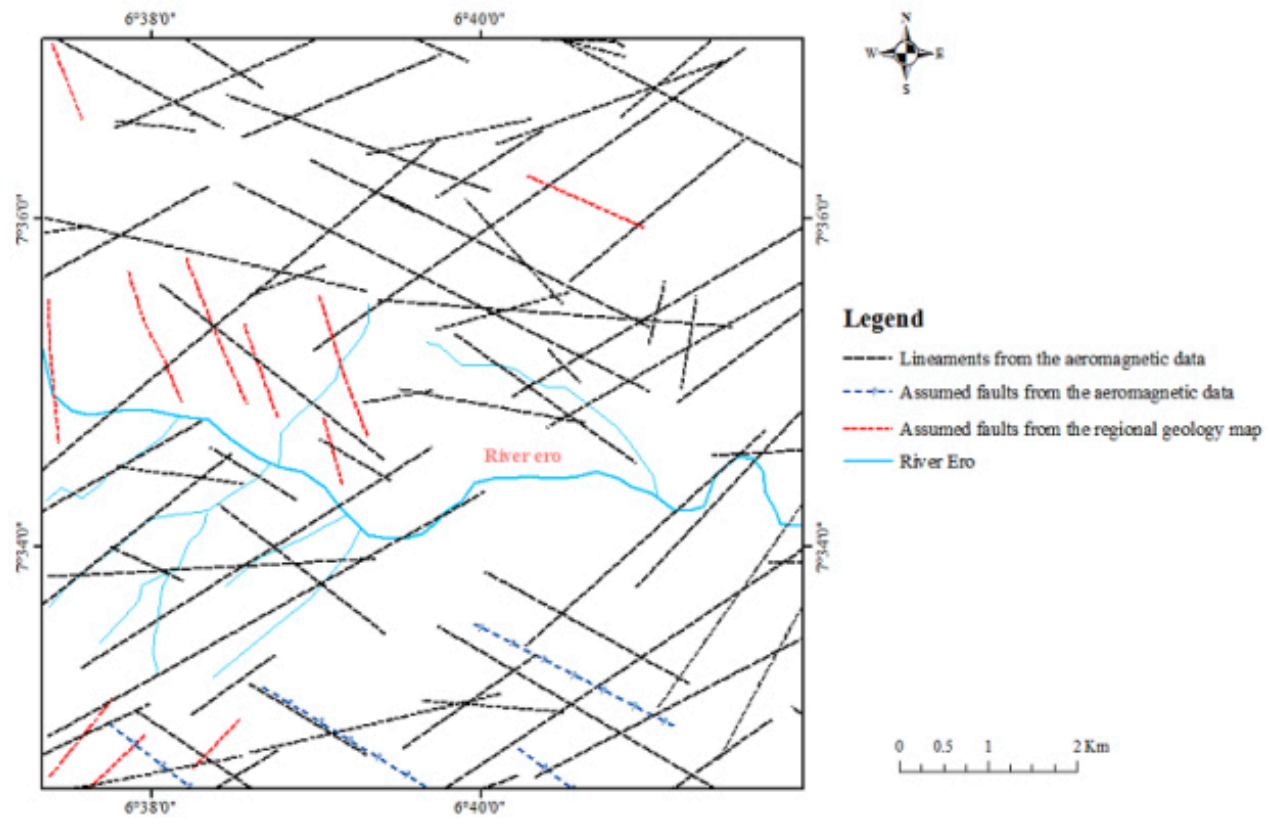

Figure 9: Lineament map of the study area.

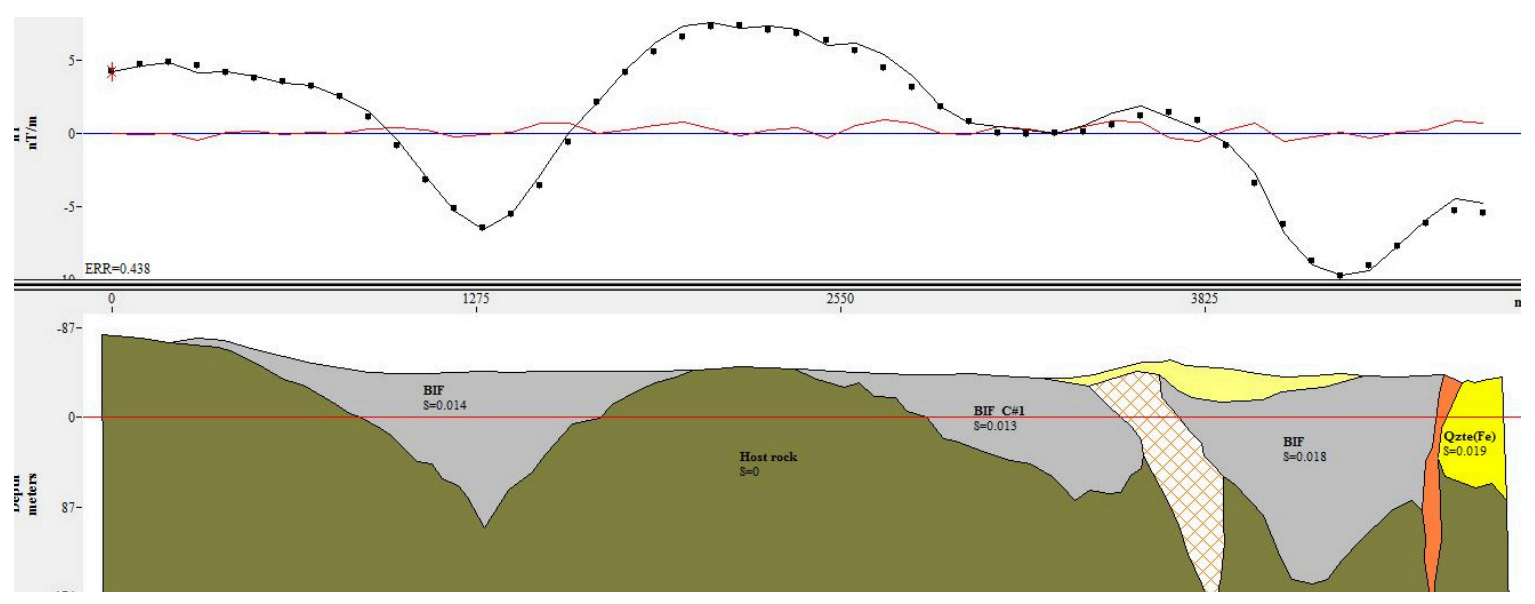

Figure 10a: 2D magnetic model of Line 1 (NW-SE).

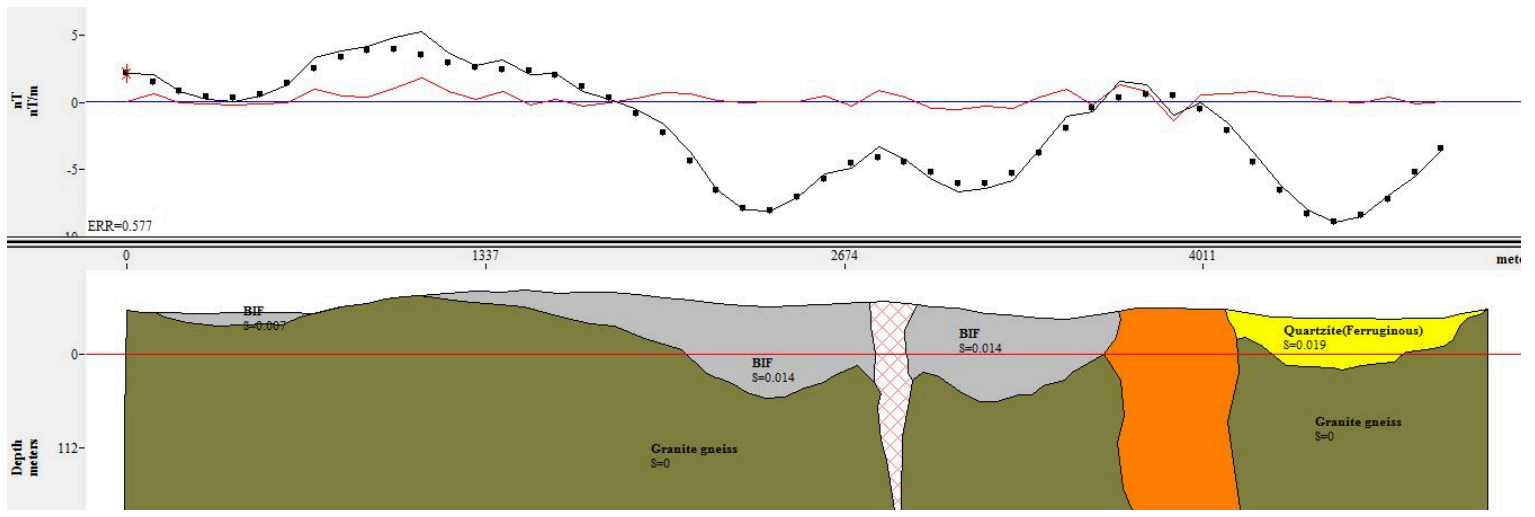

Figure 10b: 2D magnetic model of Line 2 (NW -SE). 


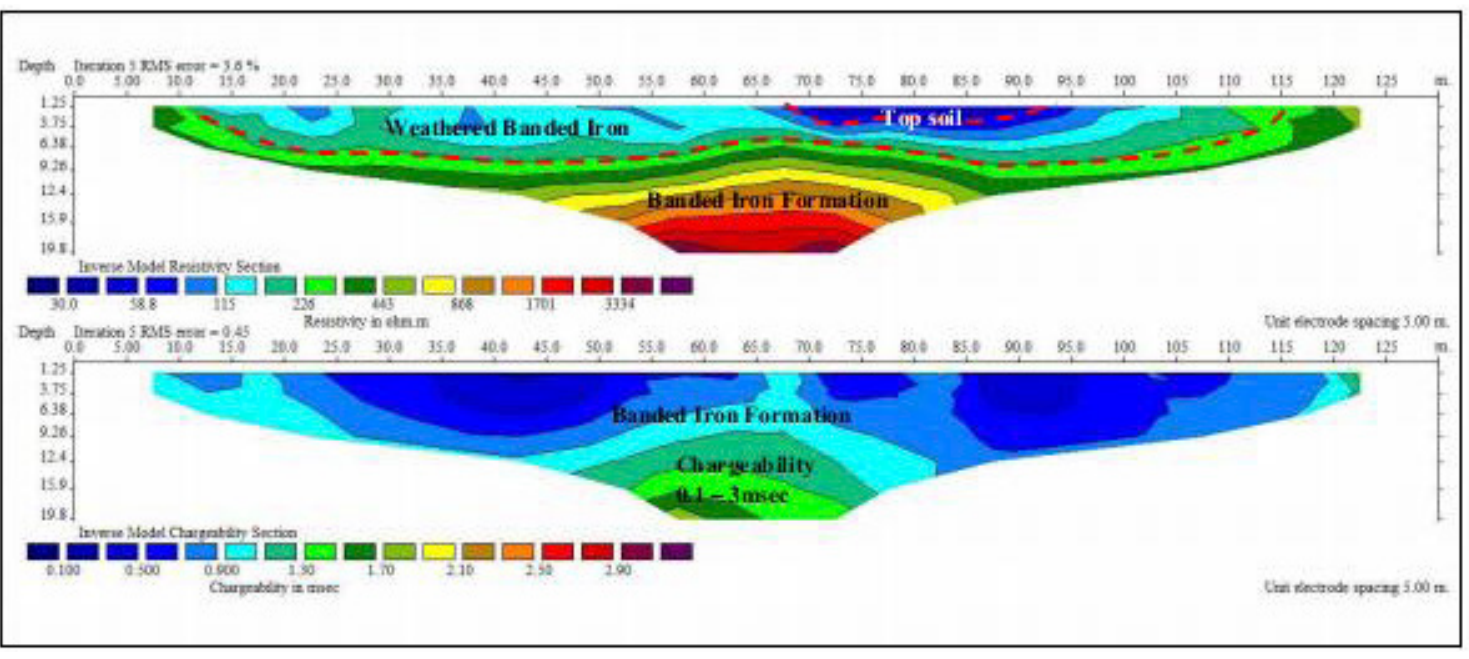

Figure 11a: Two-dimensional inverted resistivity and induced polarization model of Profile 1.

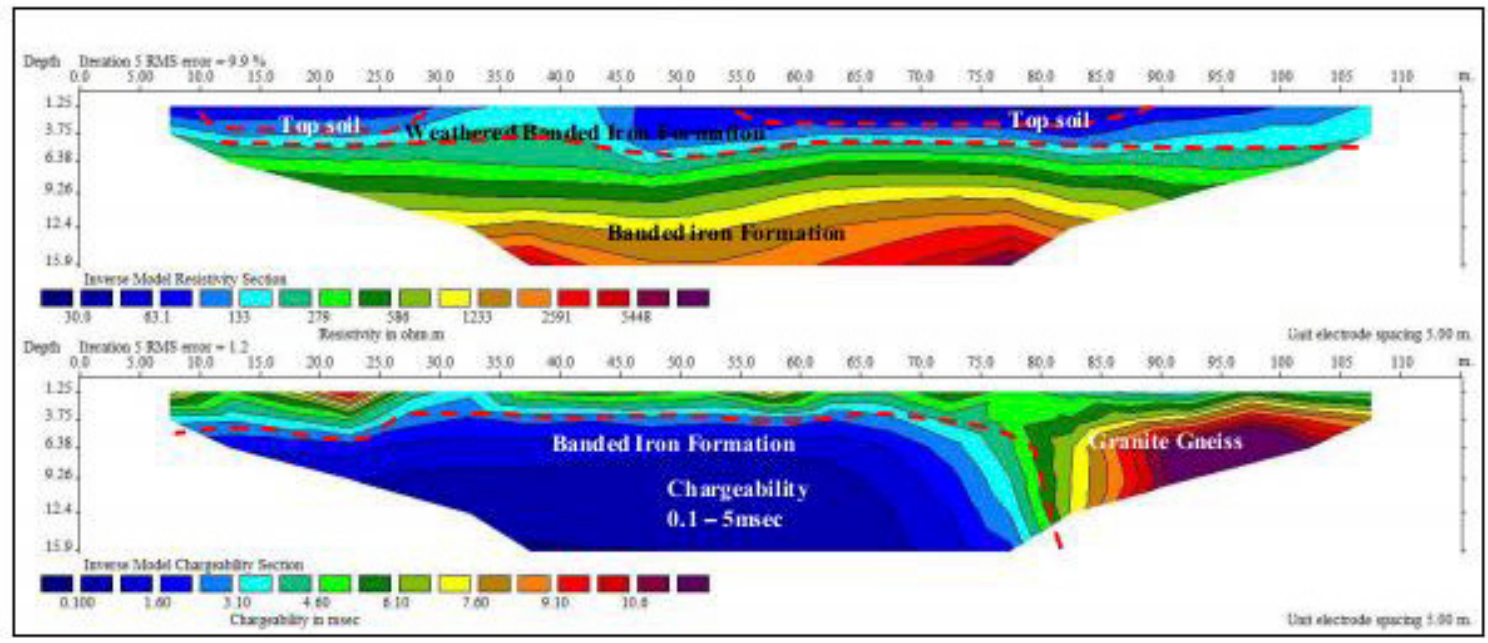

Figure $11 \mathbf{b}$ : Two-dimensional inverted resistivity and induced polarization model of Profile 2.

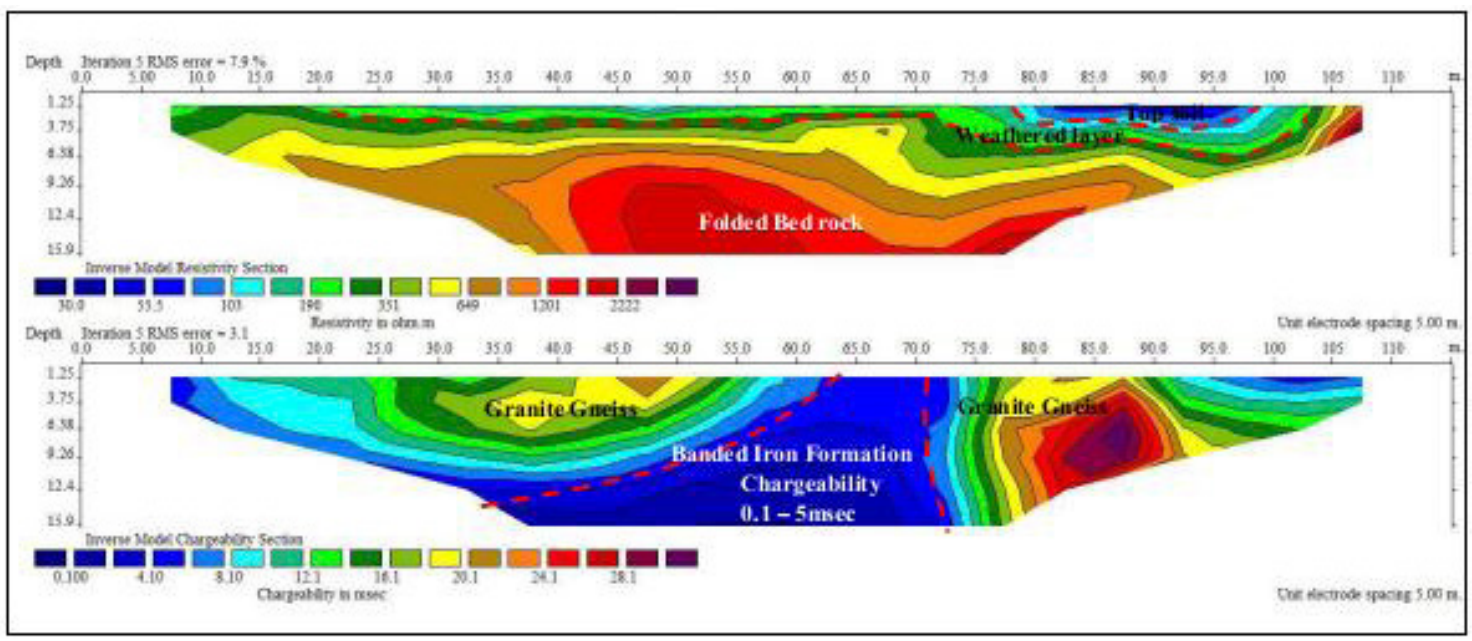

Figure 11c: Two-dimensional inverted resistivity and induced polarization model of Profile 3. 


\section{D Resistivity and IP models}

From the resistivity models (Figures $11 a-13 a$ ), the top soil (sand/clayey sand) has a depth range between $0 \mathrm{~m}$ and $4 \mathrm{~m}$, the weathered layer extends to depths of about $7 \mathrm{~m}$, below which the fresh (unweathered) basement was encountered. The iron ore was identified based on the chargeability models (Figures $11 b-13 b$ ) as zones of low chargeability ( $0.1-5 \mathrm{msec})$. This range falls within the chargeability range of magnetite and hematite [27], which are major constituents of the iron ore type occurring within the study area [12]. The high chargeability response of the granite gneiss ( $>6 \mathrm{msec}$ ) may be due to the presence of some mafic minerals disseminated within its mass. The iron body that was not easily identified in the resistivity model was clearly identified and distinguished in the chargeability models. Thus, chargeability models revealed the BIFs occurring within the granite gneiss, which is in agreement with the geology of the iron mineralization in the study area $[12,14]$. The overburden thickness and the evidence of folding patterns on the BIF observed on these models agree with the geology of the area [6]. Chargeability values of 3-5 msec could indicate an average grade of $10 \%-20 \%$ of iron, while $0.1-3 \mathrm{msec}$ could indicate an average grade of $20 \%-40 \%$ of iron ore [28]. on the basis of this observation, the iron ore within the area was inferred to have an average grade between $20 \%$ and $40 \%$, which is typical of similar ore deposits within the area (Itakpe: $36 \%$; and Agbado-Okudu: $38 \%-43 \%$ ), as documented [6]. In all, the profiles showed good fit between the observed and computed resistivity/chargeability with root-mean-square errors of less than $3.6 \%$. Field observations revealed that the geology of the study area was suitably imaged by the resistivity and chargeability simulations.

\section{Conclusion}

The results obtained from the integration of the aeromagnetic, 2D resistivity and IP methods showed that the iron ore mineralization is associated with the granite gneiss lithologic unit and occurs at a shallow depth favourable for exploitation. The BIF magnetic anomalies are characterized by spherical analytic signals and susceptibility values ranging from $0.035 \mathrm{nT} / \mathrm{m}$ to $0.06 \mathrm{nT} / \mathrm{m}$ and $0.007-0.014 \mathrm{SI}$, respectively. The resistivity ranges from $1.5 \times 10^{2}$ to $2.5 \times 10^{3}$, while the chargeability ranges from $0.1 \mathrm{msec}$ to $5 \mathrm{msec}$. From the chargeability response, the iron bodies can be said to be of average grade suitable for economic exploitation. The number and varying trend of the delineated structures indicated that the area has undergone more than one tectonic episode, which resulted in fracturing and faulting.

\section{References}

[1] The Encyclopedia Americana (1992): Grolier Inc. Vol. 15, pp 443-463.

[2] James, H.L. (1954): Sedimentary facies of iron formations. Economic Geology 49, 235-293.

[3] Amigun, J. O., Afolabi, O., Ako, B. D. (2012): Application of airborne magnetic datato mineral exploration in the Okene Iron Ore Province of Nigeria. International Research Journal of Geology and Mining, 2(6), pp 132-14.

[4] Anudu, G.K., Onuba, L. N., Onwuemesi, A. G., Ikpokonte, A. E. (2012): Analysis of aeromagnetic data over Wamba and its adjoining areas in north-central Nigeria. Earth Sciences Research Journal, 16(1), pp 25-33.

[5] Jamil Baba, Saidu Baba and Tersoo Aga (2012): Preliminary process mineralogy of Agbado - Okudu Iron ore deposit, Kogi South-Western Nigeria. Research Journal in Engineering and Applied Sciences, 1(4), pp 247-250.

[6] Raw Materials Research and Development Council (RMRDC, 2010). Steel raw materials in Nigeria. ISBN: 978-2043-79-6.

[7] Gunn, P.J. (1993). The Causes of Magnetic Responses in Massive Sulphide Ore Bodies and Their Horst Rocks

[8] Gunn, P.J. and Dentith, M.C. (1997): Magnetic Responses Associated with Mineral Deposits. AGSO Journal of Australian Geology and Geophysics, 17(2), pp 145-158.

[9] Stanley, H.W. (1990): Resistivity and Induced polarization methods. SEG investigations in geophysics. Geotechnical and environmental geophysics. Vol 1. pp 147-189

[10] Saeed, K.A. (2014): Application of Magnetometery, Electrical Resistivity and Induced Polarization for Exploration of Polymetal Deposits, A Case Study: HalabDandi, Zanjan, Iran. 2nd Intl' Conference on Advances 
in Engineering Sciences and Applied Mathematics, May 4-5, 2014 Istanbul (Turkey).

[11] Wei Zhang, Jian-Xin Liu, Zhen-Wei Guo, and XiaoZhong Tong (2010): Cole-Cole Model based on the Frequency - domain IP Method of Forward Modelling. Progress in Electromagnetics Research Symposium Proceedings, Xi'an, China, March 22-26, 2010. pp 383-386.

[12] Olade, M.A. (1978): General features of a Precambrian iron deposit and its environment at Itakpe Ridge Okene, Nigeria. Trans. Inst. Min. Metallurgy. Sect. B87 pp.81-89.

[13] Grant, N.K., Hickman, M.H., Burkholder, F.R., Powell, J.L. (1972): Kibaran Metamorphic belt in the Pan-African domain of West Africa. Nature (London) Phys. Sc., 238, pp. 90-91.

[14] Hockey R. D, Sacchi R, Graaff, W.P.F, Muotoh E.O.G. (1986): The geology of Lokoja - Auchi Area, Explanation of 1:250,000 Sheet 62 . Geological Survey of Nigeria, Bulletin No. 39. 71 p.

[15] Muecke, A., Annor, A., Neumann, U. (1996): The Algoma Type Iron-Formations of the Nigerian Metavolcano - Sedimentary Schist Belts. MineraliumDeposita 31: 113-122.

[16] Leu, L.K. (1981): Use of reduction-to-equator process for magnetic data interpretation: Presented at the 51st Ann. Internat. Mtg., Sot. Exnl. Geonhv: geophysics 47. 445 (abstract).

[17] Nabighian M.N, Grauch J.S., Hansen R.O, LaFehr T.R, Li Y, Peirce J.W, Phillips J.D, Ruder M.E., (2005): The historical development of the magnetic method in exploration, Geophysics, 70, No. 6, 33-61

[18] Roest, W.R., Verhoef, J., Pilkington, M. (1992): Magnetic interpretation using 3-D analytical Signal. Geophysics, 57, 116-125.

[19] MacLeod, I. N., K. Jones, T. F. Dai. (1993): 3-D analytic signal in the interpretation of total magnetic field data at low magnetic latitudes: Exploration Geophysics, 24, pp. 679-688.

[20] Thurston, J.B., Smith, R.S., (1997): Automatic conversion of magnetic data to depth, dip, and susceptibility contrast using the SPI (TM) method: Geophysics, 62, 807-813.

[21] Phillips, J.D. (1998). Processing and interpretation of aeromagnetic data for the Santa Cruz Basin Patahonia Mountains Area, south-central Arizona. US Geological Survey, Open-File Report 02-98.

[22] Loke, M.H. (2001): Tutorial on 2-D and 3-D electrical imaging surveys. pp 1-129.
[23] DeGroot-Hedlin, C., Constable, S.C. (1990): Occam's inversion to generate smooth dimensional models from magnetotelluric data. Geophysics, 55, 1613-1624.

[24] Onyeagocha A.C., Ekwueme B.N. (1982). "The Pre-Pan-African Structural Features of North central Nigeria”. Niger. J. Min. Geol., 19(2), pp. 74-77.

[25] Ajakaiye, D.E., Hall, D.H., Miller, T.W, Verherjen, P.J. T., Awad, M.B. and Ojo, S.B. (1986): Aeromagnetic anomalies and tectonic trends in and around the Benue Trough Nigeria. Nature, 319, pp 582-584.

[26] Olasehinde, P.I., Pal, P.C., Annor, A.E. (1990): Aeromagnetic anomalies and structural lineament in the Nigerian Basement Complex. Journal of African Earth Sciences, 11, No. 3/4, 351-355.

[27] Telford, W.M., Geldart, L.P., Sheriff, R.E., Keys, D.A. (1990): Applied Geophysics, Cambridge University Press.

[28] Rosli, S., Ahmad, S.M, Imran, A. (2012): The Study of Iron Ore Prospect using 2 - D Resistivity and Induced Polarization (IP) Method. EDGE, 17, pp 2981-2988. 